\title{
An assessment of GHG emissions and mitigation potential from Agriculture, Forestry and Other Land-Use in Cambodia
}

\author{
HAK Mao $^{1, *}$ Tomoko HASEGAWA $^{2}$ and Yuzuru MATSUOKA ${ }^{3}$ \\ ${ }^{1}$ Head of Climate Change Vulnerability and Adaptation Assessment Office, Climate Change \\ Dept. of MoE, Cambodia and Dept. of Environmental Engineering, Kyoto University \\ (C-cluster, Kyoto-Daigaku-Katsura, Nishikyo-ku, Kyoto 615-8540, Japan) \\ *E-mail: maohakccd.se@gmail.com \\ ${ }^{2}$ Center for Social \& Environmental Systems Research, National Institute for Environmental Studies \\ (16-2 Onogawa, Tsukuba, Ibaraki, 305-8506, Japan) \\ E-mail: hasegawa.tomoko@nies.go.jp \\ ${ }^{3}$ Professor, Dept. of Environmental Engineering, Kyoto University \\ (C-cluster, Kyoto-Daigaku-Katsura, Nishikyo-ku, Kyoto 615-8540, Japan) \\ E-mail: matsuoka@env.kyoto-u.ac.jp
}

\begin{abstract}
Cambodia had changed from a net carbon sink in 1994 to a net emitter in 2000 where the highest contributor of GHG emissions was land use change and forestry (51\%), followed by agriculture (45\%), energy (4\%), and waste (less than 1\%). However, Cambodia has not formulated a concrete plan for GHG mitigation in the Agriculture, Forestry and Other Land-Use (AFOLU) sector. Therefore, it is an appropriate time to propose a scenario to assess GHG emissions and mitigation potential for this sector in Cambodia. This study applies AFOLU Bottom-up Model (AFOLU-B) to estimate GHG emissions and mitigation potential based on assumed socioeconomic indicators and on ongoing policies for the AFOLU sector through taking several constraints under mitigation cost and measures into account. The results yield that GHG emissions will change from a net carbon sink ( $0.94 \mathrm{MtCO}_{2}$ eq.) in 2010 to a net emitter $\left(13.98 \mathrm{MtCO}_{2}\right.$ eq.) in this sector in 2050. In the agricultural sector, the most effective mitigation measures are applied with the cost of less than $10 \mathrm{US} \$ / \mathrm{tCO}_{2}$ eq.; rice cultivation contributes the biggest share (87\%), while in the land use change and forestry sector, the most plausible mitigation measures are applied with the cost of less than 50US $\$ / \mathrm{tCO}_{2}$ eq.; reduced impact logging generates the largest mitigation potentials (99\%) because of limited available land to apply plantations in the future. These findings are expected to provide insights for decision-makers to formulate climate change mitigation policy for the AFOLU sector.
\end{abstract}

Key words: Agriculture, Forestry and Other Land-Use; Abatement Cost; GHG emission and reduction

\section{INTRODUCTION:}

To achieve the ultimate goal of the United Nations Framework Convention on Climate Change (UNFCCC), Parties should join with the world to protect the climate system on the basis of equity and in accordance with their common but differentiated responsibilities and respective capabilities ${ }^{1)}$. On this, international communities agreed that this goal corresponds roughly to holding the increase in global average temperature below $2^{\circ} \mathrm{C}$ from pre-industrial levels ${ }^{2)}$. Several studies have shown that a fragmentation and a delay in climate policy have a substantial effect on the cost and achievability of climate targets ${ }^{3), 4}$. Participation of non-Annex-I countries of the UNFCCC including Cambodia will be a key role to achieve the target and to keep the mitigation costs low for the target ${ }^{3)}$.

GHG emissions in Cambodia had changed from a net carbon sink in 1994 to a net emitter in $2000^{5}$. The highest contributor of GHG emissions was Land Use, Land Use Change and Forestry 
(LULUCF), which accounted for 51\%, followed by agriculture $(45 \%)$, energy (4\%), and waste (less than $1 \%)^{5)}$. GHG emissions in the LULUCF sector mainly caused by the decrease of forest cover due to forest concessions granted by the government ${ }^{6,7,7), 8}$ and all biomass carbon stock in forest was assumed to be emitted in the year of deforestation.

In order to mitigate GHG emissions from the AFOLU sector, the country has developed various policies and strategies such as sustainable agricultural management and strategic plan, national forest policy and programme, and livestock management strategic plan, etc. ${ }^{9), 10), 11)}$. However, Cambodia has not formulated a concrete plan for GHG emissions mitigation in the AFOLU sector since the government has given the high priority to economic development and poverty reduction, ${ }^{9,12}$ and per capita GHG emissions were insignificant with only $0.23 \mathrm{tCO}_{2}$ in $2000^{5)}$. Besides, there is no study on the cost-benefit analysis of applying GHG mitigation measures so as to provide in-depth insights to the Government to prepare an appropriate GHG mitigation policy in the future. The analysis on possible mitigation amounts and minimum costs for Cambodia is useful to start discussion on her mitigation target, strategies and costs. Therefore, it is a good time to propose scenarios to assess GHG emissions and mitigation potential from the AFOLU sector in Cambodia.

The objectives of this study are (1) to propose and introduce the appropriate future alternatives of mitigating GHG emissions in the AFOLU sector from a view point of cost-effectiveness of mitigation measures for Cambodia; (2) to estimate GHG emissions and mitigation potential systematically and quantitatively, using the AFOLU-B model; and (3) to quantify indicators related with agriculture and land use management based on ongoing policies and used as inputs to the model to reflect real country situation. The quantifications were explained in the section 3 .

\section{METHODOLOGY}

\section{(1) Overview}

Leveraging the mitigation potential in the AFOLU sector is extremely important for Cambodia as this sector contributed more than $90 \%$ of total GHG emissions in $2000^{5)}$. In addition, the implementation of mitigation measures in this sector can result in an improvement in land management, reducing deforestation and increasing reforestation and afforestation. Hence, the application of the AFOLU-B model ${ }^{13)}$ is expected to help assess mitigation options in the future in Cambodia.

\section{(2) AFOLU Bottom-up Model for Emission Reduction}

This study applied the AFOLU-B model to estimate GHG emissions and mitigation potential for the AFOLU sector in Cambodia. The model has been developed to assess abatement costs and emission reduction for the AFOLU sector at a country level ${ }^{13)}$ and has been applied to some Asian countries so far $^{14), 15)}$. The model calculates GHG emissions and reduction potentials and abatement costs of individual mitigation measures at cost minimization under a given carbon price and assumed future agricultural production and land-use changes. The model incorporates detailed information of mitigation measures using the following inputs: 1) future assumptions of production in agricultural commodities and area of land-use change in a baseline case; 2) information on mitigation measures (e.g., cost, reduction effects, and life time); and 3) scenarios of financial allowance, which represent a willingness for emissions reduction. Future production level of the AFOLU sector is fixed, and cropland area and crop production amount and harvested area are assumed and input to the model. Yields (crop production per unit area) are calculated by dividing production by harvested area. To estimate the reduction or sequestration potential for each mitigation measure, the mitigation potential was annualized by dividing by the time the effect lasts. The time effect generally lasts after mitigation technologies applied and some of them can last for even longer time after the application.

In order to apply the model, some information in Cambodia is needed such as land use classifications, livestock population, crop yields, fertilizer consumption, etc. Given the limited country information, additional calculations and assumptions were made based on available data, historical trend, and professional insights as well as discussions with national experts. The data estimations and assumptions in this study were primarily based the relevant Government 
documents and a series of discussions with key Government officers and involved institutions to make the assumptions more precise, reliable and acceptable. The procedures to acquire the information were made in three steps.

First, relevant documents such as forest cover and management, agriculture production and management, livestock requirement and projection, and fertilizer consumption, etc. were collected from relevant institutions and subsequent discussions were made with key persons from respective institutions (Table 1) to ensure the validity and applicability of the collected information.

Second, a workshop on the "Advancement and Enhancement on Low Carbon Development Researches and Policies among Cambodia, Lao PDR, and Myanmar" was organized on 26 February 2015 in Phnom Penh, Cambodia aiming to disclose the preliminary estimation of the AFOLU sector and to collect further comments and inputs from the participants in order to improve the estimations. The workshop was attended by around 70 participants who were the representatives of Japan, Myanmar, and Cambodia.
Third, intensive interviews with relevant Government officials and experts were conducted in order to clarify assumptions and estimations.

\section{(3) Framework of the scenarios}

This study chose 2010 as the base year and 2050 as the target year. Two scenarios are assumed:

1) Baseline (BL) scenario without applying mitigation measures and

2) Countermeasure $(\mathrm{CM})$ scenario with the application of mitigation measures to reduce GHG emissions.

GHG mitigation potential is defined to be a difference of emissions between the two scenarios. In the $\mathrm{CM}$ case, we assumed different costs: less than $0,10,20,50$, and $100 \mathrm{US} \$ / \mathrm{tCO}_{2}$ eq. to estimate economical potential and $100,000 \mathrm{US} \$ / \mathrm{tCO}_{2}$ eq. to estimate technical potential. Countermeasures are assumed to be applied after 2015. And we assumed that people who are currently working in agricultural, forestry and industrial sectors as well as people who currently don't engage with those sectors could work for mitigation countermeasures under mitigation policy in the future.

Table 1: Lists of some collected documents and the interviewees

\begin{tabular}{|c|c|c|c|}
\hline Sectors & Documents & Interviewees & Explanation \\
\hline Settlement & Land reform in Cambodia $^{30)}$ & $\begin{array}{l}\text { Dr. Meng Bundarith, Director of } \\
\text { Dept. of Land Management of the } \\
\text { Ministry of Land Management, Urban } \\
\text { Planning and Construction in } 2014^{44)}\end{array}$ & $\begin{array}{l}\text { Cambodia has not developed the detail plan on } \\
\text { land use classification and the information } \\
\text { provided by Forestry Administration (MAFF). }\end{array}$ \\
\hline \multirow[t]{2}{*}{$\begin{array}{l}\text { Forest cover } \\
\text { and Grassland }\end{array}$} & $\begin{array}{l}\text { Strategy for Natural Rubber } \\
\text { Development in Cambodia } \\
(2011-2020)^{46)} \text {; National } \\
\text { Forest Pogramme (NFP) } \\
(2010-2029)^{6)}\end{array}$ & $\begin{array}{l}\text { H.E Chea Sam Ang, Deputy Director } \\
\text { General of Forestry Administration } \\
\text { (FA) of the Ministry of Agriculture, } \\
\text { Forestry and Fisheries (MAFF) } \\
\text { in } 2013^{7)}\end{array}$ & $\begin{array}{l}\text { Discussed about the forest cover target } \\
\text { as set by the Government to maintain } \\
60 \% \text { by } 2015 \text { and the future plan to manage } \\
\text { forests. The NFP is a very important document } \\
\text { for the government to follow. The NFP doesn't } \\
\text { only mean to ensure the sustainable forest } \\
\text { management but also to enhance carbon } \\
\text { sequestration and stock capacity. }\end{array}$ \\
\hline & $\begin{array}{l}\text { Forest Cover } 2010 \text { in } \\
\text { Cambodia }^{10)}\end{array}$ & $\begin{array}{l}\text { Mr. Leng Chivin, Deputy Director of } \\
\text { Forestry and Community Forestry } \\
\text { and Country Focal Point of National } \\
\text { REL/MRV Development Systems } \\
\text { of FA, (MAFF) in } 2013 \text { and } 2015^{8)}\end{array}$ & $\begin{array}{l}\text { Discussed about the land use classifications } \\
\text { since Cambodia has not develop detail land } \\
\text { classifications as recommended by IPCC. } \\
\text { The country will prepare such an information } \\
\text { in the near future. }\end{array}$ \\
\hline Crop production & $\begin{array}{l}\text { Annual Report of the } \\
\text { Agricultural Sector } \\
(2010-2013)^{26), 42)} \text {; } \\
\text { Strategy for Agriculture } \\
\text { and Water }(2010-2013)^{40)}\end{array}$ & $\begin{array}{l}\text { Mr. Am Phirum, Deputy Director of } \\
\text { Dept. of Agronomy (MAFF) in } \\
2013^{28)}\end{array}$ & $\begin{array}{l}\text { Discussed about the validity and reliability } \\
\text { of the information on cropland and production } \\
\text { and the long term crop management and } \\
\text { improvement. }\end{array}$ \\
\hline $\begin{array}{l}\text { Livestock } \\
\text { population }\end{array}$ & $\begin{array}{l}\text { The Strategic Planning } \\
\text { Framework for Livestock } \\
(2015-2024)^{11)}\end{array}$ & $\begin{array}{l}\text { Ms. Ok Savin, Deputy Director of } \\
\text { Dept. of Animal Health and Animal } \\
\text { Production (MAFF) in } 2015^{36}\end{array}$ & $\begin{array}{l}\text { Discussed about the methodology for livestock } \\
\text { demand estimation and projection and } \\
\text { the future prospective to manage livestock. }\end{array}$ \\
\hline Wetland & - & $\begin{array}{l}\text { Mr. Kong Kimsreng, Programme } \\
\text { Officer of the International Union } \\
\text { for Conservation of Nature in } 2014^{32)}\end{array}$ & $\begin{array}{l}\text { Discussed about the wetland situation in } \\
\text { Cambodia and how the country defined } \\
\text { the wetland area. }\end{array}$ \\
\hline Fertilizer & $\begin{array}{l}\text { Annual Report on Fertilizer } \\
\text { Import and Export }\end{array}$ & $\begin{array}{l}\text { Mr. Chhup Thavith, Officer of Dept. } \\
\text { of Planning and Statistics (MAFF) }\end{array}$ & $\begin{array}{l}\text { Discussed the informaton on import and } \\
\text { export of fertilizer and the reliability } \\
\text { of the data. }\end{array}$ \\
\hline
\end{tabular}




\section{(4) Mitigation measures}

The information on mitigation measures is collected from various international and domestic literatures, including the second national communication $(\mathrm{SNC})^{5)}$. Table 2 presents types of countermeasures and cost for the agricultural sector used in this study.

Technology is defined as a combination of agricultural production technology (main technology) and GHG mitigation technologies (additional technology). Characteristics of the measures including cost, mitigation effects, agricultural productivity and emission coefficient are calculated based on the combinations of the two technologies. Parameters representing the characteristics of a technology are provided by multiplying the parameters of the characteristics of the main technologies and adjustment factors of additional technologies. For example, an emission coefficient of main technology (e.g. $50 \mathrm{tCO}_{2}$ eq./ha) is adjusted by using a parameter of additional technology (e.g. 0.8 for $20 \%$ reduction technology). Therefore, countermeasures selection depends not only on cost and mitigation potential but also on combinations of the technologies. Mitigation amount of each technology is calculated from mitigation amount per unit area or animal where countermeasure is applied. The costs reported in the literatures are exchanged into costs in Cambodia using wage from NIS ${ }^{16)}$ based on the idea that the labor cost dominates the agricultural mitigation measures. Table 3 shows types of countermeasures, mitigation potential, cost, lifetime, annual applicable land area and total land area for applying

Table 2: Lists of countermeasures for the agricultural sector

\begin{tabular}{|c|c|c|c|c|c|c|c|c|}
\hline $\begin{array}{l}\text { Emission } \\
\text { sources }\end{array}$ & Countermeasures & CODE & $\begin{array}{c}\text { Cost } \\
{[\mathrm{US} \$(\mathrm{ha} \cdot \mathrm{yr})]} \\
\text { or }[\mathrm{US} \$ / \\
(\mathrm{head} \cdot \mathrm{yr})]\end{array}$ & $\begin{array}{c}\text { Mitigation } \\
{\left[\mathrm{tCO}_{2} \text { eq. } /(\text { ha } \cdot \text { yr })\right]} \\
\text { or }\left[\mathrm{tCO}_{2} \text { eq. } /\right. \\
(\text { head } \cdot \mathrm{yr})]\end{array}$ & $\begin{array}{c}\text { Change in } \\
\text { productivity } \\
\text { from baseline } \\
\text { level }[\%]\end{array}$ & $\begin{array}{c}\text { Maximum } \\
\text { application } \\
\text { ratio* }[\%]\end{array}$ & Explanation & References \\
\hline \multirow[t]{2}{*}{$\begin{array}{l}\text { Enteric } \\
\text { fermentation } \\
(3 \mathrm{~A} 1)\end{array}$} & $\begin{array}{l}\text { Improvement of } \\
\text { genetic merit of } \\
\text { dairy cows }\end{array}$ & HGM & 0.35 & 0.32 & 10.00 & 100 & $\begin{array}{l}\text { It escalated with the import of } \\
\text { Holstein genetic material for use on } \\
\text { native dairy breeds. }\end{array}$ & Bates (1998) \\
\hline & $\begin{array}{l}\text { Replacement of } \\
\text { roughage with } \\
\text { concentrated } \\
\text { feed }\end{array}$ & $\mathrm{RRC}$ & -0.05 & 0.45 & 10.00 & 100 & $\begin{array}{l}\text { Replace roughage that contains high } \\
\text { portions of structural carbohydrates } \\
\text { with concentrates to improve } \\
\text { propionate generation in rumen. }\end{array}$ & $\begin{array}{l}\text { Graus et al. (2004), } \\
\text { Shibata et al. } \\
(2010)\end{array}$ \\
\hline \multirow[t]{5}{*}{$\begin{array}{l}\text { Manure } \\
\text { management } \\
(3 \mathrm{~A} 2)\end{array}$} & $\begin{array}{l}\text { Anaerobic } \\
\text { Digestion by } \\
\text { centralised plant }\end{array}$ & $\mathrm{ADC}$ & 0.04 & 0.33 & 0.00 & 100 & $\begin{array}{l}\text { Capture and use of manure } \mathrm{CH}_{4} \\
\text { through anaerobic digesters. }\end{array}$ & Bates (2001) \\
\hline & $\begin{array}{l}\text { Daily spread of } \\
\text { manure }\end{array}$ & DSM & 0.00 & 0.33 & 0.00 & 100 & $\begin{array}{l}\text { Manure is routinely removed from a } \\
\text { confinement facility and is applied to } \\
\text { cropland within } 24 \text { hours of excretion. }\end{array}$ & $\begin{array}{l}\text { Bates (1998), IPCC } \\
(2006)\end{array}$ \\
\hline & $\begin{array}{l}\text { Dome digester } \\
\text { for cooking fuel } \\
\text { and light }\end{array}$ & CFL & -0.14 & 0.62 & 0.00 & 100 & $\begin{array}{l}\text { A small-scale unheated digesters } \\
\text { generate biogas used by households } \\
\text { for cooking and lighting }\end{array}$ & USEPA (2006) \\
\hline & $\begin{array}{l}\text { Covered } \\
\text { anaerobic } \\
\text { digesters }\end{array}$ & $\mathrm{CAD}$ & 0.52 & 0.65 & 0.00 & 100 & $\begin{array}{l}\mathrm{CH}_{4} \text { is captured by covering lagoon } \\
\text { where manure is stored and piping the } \\
\text { gas out to a flare or used on-farm. }\end{array}$ & $\begin{array}{l}\text { USEPA (1999, } \\
\text { 2003), Bates (1998, } \\
\text { 2001), IPCC (2007) }\end{array}$ \\
\hline & $\begin{array}{l}\text { Aerobic } \\
\text { decomposition }\end{array}$ & $\mathrm{AD}$ & 0.30 & 0.59 & 0.00 & 100 & $\begin{array}{l}\text { The biological oxidation of manure } \\
\text { collected as a liquid with either } \\
\text { forced or natural aeration can reduce }\end{array}$ & $\begin{array}{l}\text { Bates (1998), IPCC } \\
(2006)\end{array}$ \\
\hline \multirow[t]{3}{*}{$\begin{array}{l}\text { Rice } \\
\text { cultivation } \\
(3 \mathrm{C} 7)\end{array}$} & $\begin{array}{l}\text { Replace urea } \\
\text { with ammonium } \\
\text { sulphate }\end{array}$ & RAS & 0.23 & 0.31 & 0.00 & 100 & $\begin{array}{l}\mathrm{CH}_{4} \text { emissions from current levels. } \\
\text { Ammonium sulfate additions to soil } \\
\text { can elevate reduction potential, which } \\
\text { suppresses } \mathrm{CH}_{4} \text { production. }\end{array}$ & $\begin{array}{l}\text { USEPA (2006), } \\
\text { Graus et al. (2004) }\end{array}$ \\
\hline & $\begin{array}{l}\text { Midseason } \\
\text { drainage }\end{array}$ & MD & 0.00 & 1.15 & 0.00 & 32 & $\begin{array}{l}\text { Rice fields are dried three times } \\
\text { within a growing period. Not applied } \\
\text { on rain-fed areas. }\end{array}$ & USEPA (2006) \\
\hline & $\begin{array}{l}\text { Off-season } \\
\text { incorporation of } \\
\text { rice straw }\end{array}$ & OIR & 0.23 & 0.87 & 0.00 & 100 & $\begin{array}{l}\text { Shifting straw amendment from } \\
\text { in-season to off-season can reduce } \\
\text { availability of dissolved organic } \\
\text { carbon and methanogens. }\end{array}$ & USEPA (2006) \\
\hline \multirow[t]{3}{*}{$\begin{array}{l}\text { Managed } \\
\text { soils } \\
(3 \mathrm{C} 4-3 \mathrm{C} 6)\end{array}$} & $\begin{array}{l}\text { High efficiency } \\
\text { fertilizer } \\
\text { application }\end{array}$ & $\mathrm{HEF}$ & 0.03 & 0.00 & -10.00 & 100 & $\begin{array}{l}\text { Apply nitrogen fertilizer is divided } \\
\text { into three smaller increments during } \\
\text { crop uptake period to reduce nitrogen } \\
\text { availability for leaching, nitrification, } \\
\text { denitrification and volatilization. }\end{array}$ & $\begin{array}{l}\text { USEPA (2006), } \\
\text { Hendriks et al. } \\
\text { (1998), } \\
\text { Amann et al. (2005) }\end{array}$ \\
\hline & $\begin{array}{l}\text { Tillage and } \\
\text { residue } \\
\text { management }\end{array}$ & TRM & 0.35 & 0.00 & 0.00 & 100 & $\begin{array}{l}\text { Conversion fertilizational tillage to } \\
\text { no till where soils are disturbed and } \\
\text { less and more crop residue is retained. } \\
\text { Avoiding the burning of residues also } \\
\text { avoids emissions. }\end{array}$ & $\begin{array}{l}\text { USEPA (2006), } \\
\text { IPCC (2007), } \\
\text { Smith et al. (2007) }\end{array}$ \\
\hline & $\begin{array}{l}\text { Slow-release } \\
\text { fertilizer }\end{array}$ & SRF & 8.21 & 0.03 & 0.00 & 100 & $\begin{array}{l}\text { Coated or tablet fertilizer releases } \\
\text { nitrogen slowly over a } 30 \text {-day period } \\
\text { and increase fertilizer-use efficiency. }\end{array}$ & $\begin{array}{l}\text { USEPA (2006), } \\
\text { Akiyama et al. } \\
(2010)\end{array}$ \\
\hline
\end{tabular}


Table 3: Lists of countermeasures for the LULUCF sector

\begin{tabular}{|c|c|c|c|c|c|c|c|}
\hline Countermeasures & CODE & $\begin{array}{c}\text { Cost } \\
{[\mathrm{US} \$(\mathrm{ha} \cdot \mathrm{yr})]^{*}}\end{array}$ & $\begin{array}{c}\text { Mitigation } \\
\text { effect of } \mathrm{CO}_{2} \\
\text { reduction } \\
{\left[\mathrm{tCO}_{2}(\mathrm{ha} \cdot \mathrm{yr})\right]} \\
\end{array}$ & $\begin{array}{c}\text { Annual } \\
\text { applicable land } \\
\text { area** } \\
{[1,000 \text { ha/year }]}\end{array}$ & $\begin{array}{c}\text { Total land areas for } \\
\text { applying technologies } \\
{[1,000 \mathrm{ha}]}\end{array}$ & $\begin{array}{c}\text { Period of } \\
\text { cost**** } \\
\text { [year] }\end{array}$ & $\begin{array}{c}\text { Effective period } \\
\text { of measures } \\
\text { [year] }\end{array}$ \\
\hline Plantation-short rotation & PSR & 47.25 & 13.57 & 0.22 & 2.19 & 10.0 & 10.0 \\
\hline Plantation-long rotation & PLR & 58.47 & 18.90 & 0.06 & 2.19 & 35.0 & 35.0 \\
\hline Reforestation-fast growing species & RFS & 39.75 & 30.86 & 0.18 & 2.19 & 12.0 & 12.0 \\
\hline Reforestation-slow growing species & RSS & 52.50 & 30.80 & 0.06 & 2.19 & 35.0 & 35.0 \\
\hline Reduced impact logging & RIL & 31.14 & 5.13 & 862.40 & $10,348.80$ & 12.0 & 12.0 \\
\hline Enhanced natural regeneration & ENR & 10.75 & 7.33 & 0.15 & 2.19 & 15.0 & 15.0 \\
\hline Agro-forestry & AGF & 7.97 & 43.45 & 0.22 & 2.19 & 10.0 & 10.0 \\
\hline
\end{tabular}

technologies in the LULUCF sector used in this study. Then, the emissions reduction potential is calculated within the model based on the assumption that the annual effect will last for the time after introducing the measures (i.e. forest plantations). To reflect a characteristic of land-based mitigation measures in terms of mitigation cost and effects lasting over years, information of reduction effects, costs, and area used for the mitigation measures implemented in a year are passed to the next year. See (Hasegawa and Matsuoka, 2013) for more details ${ }^{13)}$.

\section{THE PRESENT AND FUTURE QUANTIFICATIONS}

Data quantifications and assumptions were made to estimate GHG emissions both in the base and target year while countermeasures applied to reduce emissions were selected from Table 2 and 3.

\section{(1) Land use change}

Land use classification in this study followed the IPCC guideline in which six categories were classified including cropland, grassland, forestland, settlement, wetland, and other land ${ }^{27}$. The detail information on the assumptions and projection of land use change in 2010 and 2050 is shown in Table 4. The assumptions were made based on the relevant documents and direct interviews with the relevant persons as shown in table 1 above. Cropland in 2010 was collected from MAFF $^{27), 28)}$ and NIS ${ }^{26)}$, while towards 2050 was collected from $\mathrm{MoE}^{5)}$. Grassland in 2010 was collected from $\mathrm{FAO}^{29)}$, while towards 2050 was referred to historical trend. It was observed that grassland had decreased annually by 80 thousand ha between
1992 and $1996^{5)}$ due to the increase of the agricultural land and the trend is expected to remain constant as the country needs more agricultural land. Therefore, this study assumed that grassland will continue to decrease until 2020 and is assumed to remain constant between 2020 and 2050 as the Government has to preserve for animal habitats and feeding. Forest land in 2010 was collected from $\mathrm{RGC}^{7,8), 10)}$, while in 2050 is assumed to be the same as the Government's target to maintain forest cover by $60 \%^{7,10)}$. Settlement in 2010 was collected from Sovan $^{30,44)}$ and is assumed to increase to be proportionated to the population growth, which was around $1.14 \%$ per year towards $2050^{31)}$. Wetland in 2010 was not fully acquired. According to an interview with Kim Sreng ${ }^{32)}$, wetland in Cambodia is quite large covering the flooded forest, rice field and settlement (floating houses). However, the net wetland area in Cambodia was 83.46 thousand ha in $1996-1997^{33), 34)}$. This study merged the inland water into wetland and is assumed to remain constant until 2050. Lastly, the other land was subtracted from the total country land and the above-mentioned land use categories. It can be observed from the table that the other land decreased substantially; however, the decrease did not only result from the increase of forest land but also from other land use categories.

Table 4: Land use change in 2010 and 2050

\begin{tabular}{lcc}
\hline Land use categories [1,000 ha] & 2010 & 2050 \\
\hline Cropland & 3,227 & 4,400 \\
Grassland & 1,500 & 700 \\
Forest land & 10,364 & 10,862 \\
Settlement & 1,000 & 1,573 \\
Otherland & 1,460 & 15 \\
Wetland & 553 & 553 \\
\hline Total & $\mathbf{1 8 , 1 0 4}$ & $\mathbf{1 8 , 1 0 4}$ \\
\hline
\end{tabular}




\section{(2) Livestock population}

The Government of Cambodia has set a goal to ensure food security, increase incomes, create employment and improve nutrition status for all people $^{8)}$. On this, National Strategic Planning Framework for Livestock (2015-2025) has been prepared with the objective to improve the livelihoods of small producers, household income and food security and to provide a safe and sufficient supply of livestock products to the consumers as well as for export ${ }^{11), 35)}$. On this, the government did not clearly point out how to feed the projected increases of livestock population; however, it reiterated that there is a need to improve animal health and increase of both quantity and quality of feeding sources ${ }^{11)}$. The detail information on the livestock requirement and projection in 2010 and 2050 is shown in Table 5.

The number of dairy cattle was not acquired in 2010; it was, therefore, estimated from the total milk consumption ${ }^{11)}$. Milk consumption was projected to increase from 108 thousand tons in 2010 to 191 thousand tons in 2020 and $75 \%$ of which was imported. Around 50 thousand dairy cattle are needed to produce 191 thousand tons of milk $^{11)}$ (one dairy cattle can produce around 3.8 tons of milk per year). Then, the number of dairy cattle in 2010 was estimated. Besides, Cambodia could accommodate around 27 thousand dairy cattle in $2020^{11)}$ and we expected that the number of dairy cattle will increase in the future due to the increase of using improved dairy breeds and locally available feeding resources ${ }^{11)}$. Hence, this study assumed that the number of dairy cattle from 2020 to 2050 will annually grow to be similar to the projected increasing rate of milk consumption between 2010 and 2020, which is around $6 \%{ }^{11)}$. The information on cattle and buffalo, sheep, goat, horse, pig and poultry population in 2010 was collected from $\mathrm{MAFF}^{26), 36)}$ and $\mathrm{NIS}^{11,25)}$. Cattle and buffalo requirement towards 2020 was projected by $\mathrm{RGC}^{11)}$, while towards 2050, this study assumed the annual growth rate to be similar to the Government's projection $^{9)}$, which is $3 \%$ per year. However, the number of buffalo is assumed to increase until 2030 and to remain constant until 2050 as buffalo meat is not preferred by Cambodians. Meanwhile, the number of horses, goats, and sheep towards 2050 is assumed to be similar to 2010 as most of Cambodians do not eat the meat from those animals.
The number of pig requirement towards 2020 was projected by the Government ${ }^{11)}$, while towards 2050 , this study assumed the annual growth rate to be similar to the Government's projection ${ }^{9)}$, which is $3 \%$ per year. Furthermore, the poultry requirement towards 2020 was also projected by the Government ${ }^{11)}$. It was indicated that the poultry requirement will grow slower than those of cattle and pigs in the future ${ }^{11)}$. Hence, this study assumed that the poultry requirement will grow annually by around $1.5 \%$ towards 2050 . The share of the duck requirement in 2050 is assumed to be similar to 2010 's data, which was around $16 \%$ of the total poultry.

Table 5: Livestock requirement in 2010 and 2050

\begin{tabular}{lcc}
\hline Types of livestock [1,000 head] & 2010 & 2050 \\
\hline Dairy cattle & 7 & 27 \\
Meat cattle & 3,547 & 8,842 \\
Buffaloes & 640 & 883 \\
Sheep & 5 & 5 \\
Goats & 35 & 35 \\
Horses & 24 & 24 \\
Pigs & 3,047 & 9,915 \\
Chickens & 21,261 & 47,268 \\
Ducks & 4,050 & 9,003 \\
\hline
\end{tabular}

\section{(3) Cropland and crop yields}

Cropland in this section refers to harvested areas. This study classified cropland areas into six main categories to make it more precise and easy to estimate. The detailed crop land classification and aggregation used for this study is shown in Table 6, while Table 7 presents the detail information on cropland area in 2010 and 2050. Each cropland area in 2010 was collected from $\mathrm{FAO}^{29)}$, MAFF ${ }^{26), 27), 28)}$, and NIS ${ }^{25)}$. The rice harvested area towards 2050 was extrapolated from the historical trend. The rice harvested area had increased notably between 1980 and 2013 due to the increase of the population and export orientation and this trend is expected to remain constant in the future due to the population growth, available agriculture technologies and irrigation systems, and agriculture extension ${ }^{26), 27), 28)}$. In this study, we simply assumed the future increase in rice harvested area based on the historical trend since we did not have sufficient government plan on it. Since Cambodia's GDP per capita in 2050 was projected to grow to around 4,000 US\$/capita/year (at 2000 constant price) ${ }^{37}$, we judged that future 
food diet might change slightly but not largely. Grain consumption is acceptable to be assumed to keep increasing at historical growth at the economic level; however, we would like to address creating more reliable future projection in the future study.

The Government will also increase cultivation times for some provinces where the irrigation systems are available so as to achieve the target to export one million tons of milled rice by $2015^{28), 38)}$. The irrigation system in Cambodia covered $32 \%$ in 2010, while the rest was rain-fed agriculture ${ }^{39}$.

The rice yield in 2010 was 3 tons $/ \mathrm{ha}^{26), 27)}$, which was lower than LAO PDR (3.5 tons/ha) and Vietnam (4.9 tons/ha $)^{40)}$ due to the lack of irrigation system and low fertilizer usage, etc. The yield was projected to increase to about 3.3 tons/ha by $2018^{9}$. Furthermore, this study assumed that the rice yield in 2050 will increase to be similar to the world average $^{41)}$, which is 5.3 tons $/$ ha. This is because the Government will rehabilitate the existing and construct more irrigation networks for crop intensification as well as increase fertilizer consumption. Similarly, the maize harvested area was observed to increase about 2 times between 1980 and 2010 with the average annual growth rate of around 2.12\%; however, it was observed to decrease between 1990 and 2005 and to increase from 2005 onward $^{26), 27), 42)}$. This study assumed that the maize harvested area will continue to grow until 2030 and is assumed to remain constant through to 2050. The maize yield in 2010 was 3.6 tons $/ \mathrm{ha}^{40)}$ and increased to 4.4 tons/ha in $2012^{43)}$. This study assumed that the maize yield will increase to be similar to the world average in $2050^{41)}$, which is about 6.1 tons/ha. The yield increase is due mainly to available technologies and increasing demand of food for both people and animals as Cambodia is expected to become a developed country by $2050^{9}$. Currently, most of livestock animals are fed in pasture land ${ }^{11,36)}$. Future situation might be changed and some animals might be grown by grains as well. Future increase in grains fed to livestock animals is partly considered as increase in production of crops including maize. And Cambodia as a Party to the Cartagena Protocol promulgated a Law on Biosafety in 2008 and prepared a National Action Plan on Biosafety and Modern Biotechnology (2010-2014), accordingly, in order to illustrate the government's commitment to interacting with the world community for safe handling of Genetically
Modified Organism (GMO) products as stated in the Protocol ${ }^{45)}$.

The vegetable, fruit, and nut harvested areas were significantly increased between 1980 and $2010^{26)}$ and is expected to continue increase especially the land for cassava and mango as they are the main industrial crops for export ${ }^{40)}$. This study assumed that the harvested areas will increase until 2020 and is assumed to remain constant until 2050 since the increase of these areas may come at the cost of forest area. The cassava yield in 2010 was 22.7 tons $/ \mathrm{ha}^{40)}$, the highest yield in the region. Therefore, this study assumed that the yield in 2050 is the same as in 2010.

The harvested oil crop area had increased from 1980 to 2005 and decreased afterward ${ }^{26)}$. Therefore, this study assumed the harvested area in 2050 to be similar to 2005 . The main driver in this category is soybean, which is the important source of food for human-beings. The soybean yield in 2010 was 1.5 tons/ha ${ }^{40)}$ and increased to 1.5 and 1.7 tons/ha in 2010 and 2012 43 , respectively. Due to limited country information, this study assumed that the yield in 2050 will increase to be in proportion to the historical growth between 2002 and 2010, which was 0.05 ton/year. The soybean yield is, therefore, expected to increase to 3.4 tons/ha by 2050 , which is similar to the world average (3.2 tons/ha $)^{41)}$.

The harvested sugar cane area had increased from 2 thousand ha in 1980 to 17 and 29 thousand ha in 2010 and $2013^{42)}$, respectively. However, the expansion of this crop came at the expense of forest areas, which were contrary to the Government's target. This study assumed the harvested area in 2050 to be the same as in 2013. The sugar cane yield in 2010 was 19.7 tons/ha ${ }^{27)}$ and increased to 33.2 tons/ha in $2012^{43)}$, which seemed high enough in Cambodia; it is, therefore, assumed to remain constant until 2050.

The main driver of the harvested other crop area is rubber plantation area, which the Government is planned to increase to about 400 thousand ha by $2020^{46)}$ and the plantation area is almost reached the target recently ${ }^{42)}$. It was observed that the expansion of the land may come at the cost of forest area. Thus, this study assumed that the total harvested area of other crop will increase to about 430 thousand ha in 2020 and is assumed to remain constant until 2050. The rubber yield in 2010 was 1.1 tons/ha ${ }^{43)}$ and was projected to increase to around 1.7 tons/ha in $2018^{9)}$. 
Due to limited information, the yield through to 2050 is extrapolated from the historical growth.

Table 6: Crop land classification and aggregation

\begin{tabular}{ll}
\hline Definition & Composition \\
\hline $\begin{array}{l}\text { Rice production } \\
\text { Other coarse grain } \\
\text { production }\end{array}$ & $\begin{array}{l}\text { Rice } \\
\text { Megetable, fruits, and }\end{array}$ \\
$\begin{array}{l}\text { Cassava, Sweet potatos, Vegetables, } \\
\text { nung bean, Bananas, Mangoes, } \\
\text { Mangosteens, Guavas, Oranges, }\end{array}$ \\
$\begin{array}{l}\text { Lemons and Limes, Pineapples, Fruit } \\
\text { Oil crop production }\end{array}$ & $\begin{array}{l}\text { Peanuts, Soybeans, Sesame, Coconuts, } \\
\text { Oilseeds, etc. }\end{array}$ \\
$\begin{array}{l}\text { Sugar crop production } \\
\text { Other crop production cane }\end{array}$ & $\begin{array}{l}\text { Rubber, Tobacco, Jute, Coffee, Green } \\
\text { pepper, and Chillies and Peppers }\end{array}$ \\
\hline
\end{tabular}

Table 7: Crop land assumptions and projection

\begin{tabular}{lcc}
\hline Cropland types [1,000 ha]* & 2010 & 2050 \\
\hline Paddy rice & 2,777 & 5,357 \\
Other coarse grain & 190 & 288 \\
Vegetable, fruits, and nut & 401 & 763 \\
Oil crop & 139 & 230 \\
Sugar crop & 17 & 29 \\
Other crops & 208 & 430 \\
\hline Total & $\mathbf{3 , 7 3 2}$ & $\mathbf{6 , 9 7 0}$ \\
\hline
\end{tabular}

* Cropland here refers to harvested land areas

\section{(4) Fertilizer consumption}

Cambodia has a comparatively low fertilizer usage rate; the amount of ammonia applied in paddy cultivation was one third that of Lao PDR and Thailand, and $15 \%$ that of Vietnam ${ }^{43)}$. Nitrogen fertilizer per unit of harvested area by crop is estimated by using the cross-entropy methodology ${ }^{47)}$ using total fertilizer consumption (214 thousand tons in $2010^{35), 48)}$ ) and fertilizer input per harvested area by crop in $2010^{49)}$. Fertilizer supply in Cambodia has increased rapidly over the last few years, especially since the launch of the rice export policy. Hence, this study assumed that fertilizer consumption will increase in proportion to the projected increase of crop yields in the future. The $\mathrm{FAO}^{50)}$ study showed clear relationships between fertilizer amount and crop yields then we assumed fertilizer increases in proportion to crop yields.

\section{RESULTS}

The emission sources used in this study followed IPCC $(2006)^{25)}$. Table 8 indicates GHG emissions in the BL case (without mitigation technologies) from agriculture and LULUCF sectors in a 10-year interval from 2010 to 2050, while Table 9 presents GHG mitigation potential in a 10-year interval, applied from 2020 to 2050 .

Table 8: GHG emissions in agricultural and LULUCF sectors in the BL case

\begin{tabular}{|c|c|c|c|c|c|c|}
\hline Emission sources [ $\left[\mathrm{MtCO}_{2} \mathrm{eq}\right.$./year] & CODE & 2010 & 2020 & 2030 & 2040 & 2050 \\
\hline \multicolumn{7}{|l|}{ The agricultural sector } \\
\hline Enteric fermentation & $3 \mathrm{~A} 1$ & 4.33 & 4.47 & 6.02 & 8.07 & 10.83 \\
\hline Manure management & $3 \mathrm{~A} 2$ & 0.61 & 0.79 & 0.99 & 1.24 & 1.57 \\
\hline Rice cultivation & $3 \mathrm{C} 7$ & 17.09 & 21.27 & 26.48 & 32.96 & 32.96 \\
\hline Managed soil & $3 \mathrm{C} 4-3 \mathrm{C} 6$ & 4.12 & 6.90 & 10.57 & 16.52 & 21.45 \\
\hline Sub-total & & 26.14 & 33.44 & 44.06 & 58.79 & 66.81 \\
\hline \multicolumn{7}{|l|}{ The LULUCF sector* } \\
\hline $\begin{array}{l}\text { Changes in forest and } \\
\text { other woody biomass stocks }\end{array}$ & $5 \mathrm{~A}$ & -46.01 & -45.69 & -45.69 & -45.69 & -45.69 \\
\hline Forest and grassland conversion & $5 \mathrm{~B}$ & 18.93 & -7.13 & -7.13 & -7.13 & -7.13 \\
\hline Sub-total & & -27.08 & -52.83 & -52.83 & -52.83 & -52.83 \\
\hline Total & & -0.94 & -19.39 & -8.76 & 5.96 & 13.98 \\
\hline
\end{tabular}

Table 9: Mitigation potentials (CM) in agricultural (10US $\$ / \mathrm{tCO}_{2}$ eq.) and LULUCF (50US\$/tCO ${ }_{2}$ eq.) sectors

\begin{tabular}{lccccc}
\hline Mitigation measures [MtCO ${ }_{2}$ eq./year] & CODE & 2020 & 2030 & 2040 & 2050 \\
\hline The agricultural sector & & & & & \\
Daily spread of manure & DSM & 0.16 & 0.21 & 0.28 & 0.38 \\
Dome digester and biogas is used as energy & CFL & 0.04 & 0.06 & 0.08 & 0.11 \\
High genetic merit & HGM & 0.39 & 0.52 & 0.70 & 0.94 \\
Replacement of roughage with concentrates & RRC & 0.57 & 0.77 & 1.03 & 1.38 \\
Replace urea with ammonium sulphate & RAS & 1.19 & 1.48 & 1.85 & 1.85 \\
Midseason drainage in rice paddy & MD & 6.91 & 8.60 & 10.70 & 10.70 \\
Off-season incorporation of rice straw & OIR & 2.16 & 2.68 & 3.34 & 3.34 \\
Convert fertilizational tillage to no-tillage & CFT & 0.02 & 0.02 & 0.03 & 0.02 \\
High efficiency fertilizer application & HEF & 0.96 & 1.23 & 1.59 & 1.81 \\
Tillage and residue management & TRM & 0.0 & 0.0 & 0.0 & 0.03 \\
Slow-release fertilizer & SRF & 0.0 & 0.0 & 0.0 & 0.0 \\
\hline Sub-total & & 12.39 & 15.57 & 19.60 & 20.55 \\
\hline The LULUCF sector & & & & & \\
Plantation-short rotation & PSR & 0.0 & 0.0 & 0.0 & 0.0 \\
Plantation-long rotation & PLR & 0.0 & 0.0 & 0.0 & 0.0 \\
Reforestation-fast growing species & RFS & 0.01 & 0.01 & 0.01 & 0.01 \\
Reforestation-slow growing species & RSS & 0.0 & 0.0 & 0.0 & 0.0 \\
Enhanced natural regeneration & ENR & 0.0 & 0.0 & 0.0 & 0.0 \\
Agro-forestry & AGF & 0.01 & 0.01 & 0.01 & 0.01 \\
Reduced impact logging & RIL & 8.87 & 8.87 & 8.87 & 8.87 \\
\hline Sub-total & & 8.89 & 8.89 & 8.89 & 8.89 \\
\hline Total & & $\mathbf{2 1 . 2 8}$ & $\mathbf{2 4 . 4 6}$ & $\mathbf{2 8 . 4 9}$ & $\mathbf{2 9 . 4 4}$ \\
\hline
\end{tabular}

\section{(1) GHG emissions from the AFOLU sector}

The results yield that the AFOLU sector in Cambodia was a net sink with total carbon sink of around $0.94 \mathrm{MtCO}_{2}$ eq./year in 2010 and becomes a net emitter with total GHG emissions of around $13.98 \mathrm{MtCO}_{2}$ eq./year in 2050 . GHG emissions from the agricultural sector are projected to increase about 3 times in 2050 compared to 2010. Among them, rice cultivation $(3 \mathrm{C} 7$, this code represents categories of emission and sinks in IPCC $(2006)^{25)}$ ) was the highest contributor, contributing about $65 \%$ of total GHG emissions in 2010 and is projected to increase about 2 times in 2050; followed by enteric 
fermentation (3A1), which contributed about $17 \%$ in 2010 and is expected to increase about 3 times in 2050. Meanwhile, managed soil (3C4-3C6) contributed to about $16 \%$ in 2010 and will increase about 5 times, which is the highest incremental rate among other sources. The smallest contributor was manure management (3A2), contributing to about $2 \%$ in 2010 and will increase about 2 times in 2050.

The LULUCF sector was a net sink with total carbon sink of around $27 \mathrm{MtCO}_{2}$ eq./year in 2010 . Among them, change in forest and other woody biomass stocks (5A) contributed to about $72 \%$, while the rest contributed by forest and grassland conversion (5B). Carbon sinks from 2020 to 2050 in 5B shows carbon uptake along with growth of planted forest in 2015 to meet the Government's target in 2015. The result yields that the sink capacity increases significantly from 2010 to 2020 and remains constant until 2050.

\section{(2) Mitigation potentials in the agricultural sector}

Table 10 indicates that the higher the costs the larger the economic mitigation potentials in 2050 . The result illustrates that the cost of less than 0US $\$ / \mathrm{tCO}_{2}$ eq. generates a mitigation potential of $5.96 \mathrm{MtCO}_{2}$ eq./year. The rice cultivation $(3 \mathrm{C} 7)$ is the largest contributor, followed by enteric fermentation (3A1), while managed soil (3C4-3C6) cannot be applied under the cost of less than OUS $\$ / \mathrm{tCO}_{2}$ eq. Meanwhile, the cost of less than 10US $\$ / \mathrm{tCO}_{2}$ eq. generates emissions reduction potential of about $20.55 \mathrm{MtCO}_{2}$ eq./year. The rice cultivation (3C7) still contributes the biggest emissions reduction potential of about $77 \%$, followed by enteric fermentation (3A1) (11\%), while managed soil (3C4-3C6) contributes around $1.9 \%$. The manure management (3A2) contributes the smallest share of $2 \%$. The cost ranging over $10 \mathrm{US} \$ / \mathrm{tCO}_{2}$ eq. does not cause a great increase in emissions reduction potential. This indicates that agricultural countermeasures are relatively low cost and most of the effects are applied with the cost of less than 10US $\$ / \mathrm{tCO}_{2}$ eq. The maximum mitigation potential without considering economic constraints (technical potential) is expected to reduce emissions by $22.65 \mathrm{MtCO}_{2}$ eq./year in 2050 , about 1.5 times higher than the cost of less than $10 \mathrm{US} \$ / \mathrm{tCO}_{2}$ eq.
Table 10: GHG mitigation potentials of the agricultural sector in different costs (US\$/ $/ \mathrm{tCO}_{2} \mathrm{eq}$ ) in 2050

\begin{tabular}{|c|c|c|c|c|c|c|c|}
\hline $\begin{array}{l}\text { Mitigation potential } \\
{\left[\mathrm{MtCO}_{2} \text { eq./year }\right]}\end{array}$ & CODE & 0 & 10 & 20 & 50 & 100 & Max.* \\
\hline Enteric fermentation & 3A1 & 0.30 & 1.04 & 0.94 & 0.98 & 0.98 & 0.97 \\
\hline Manure management & $3 \mathrm{~A} 2$ & 0.0 & 0.38 & 0.58 & 0.55 & 0.55 & 0.56 \\
\hline Rice cultivation & $3 \mathrm{C} 7$ & 5.66 & 17.26 & 17.26 & 17.25 & 17.25 & 17.25 \\
\hline Managed soil & 3C4-3C6 & 0.0 & 1.85 & 2.65 & 3.88 & 3.88 & 3.87 \\
\hline Total & & 5.96 & 20.53 & 21.43 & 22.65 & 22.65 & 22.65 \\
\hline
\end{tabular}

\section{(3) Mitigation potentials in the LULUCF Sector}

Table 11 shows GHG emissions mitigation potential in the different costs in Cambodia. This table indicates that the reduced impact logging dominated the other mitigation measures because the land for forest plantation is limited due to cropland and settlement expansion. The result yields that the cost of less than 0US\$/tCO ${ }_{2}$ eq. generates a mitigation potential of around $0 \mathrm{MtCO}_{2}$ eq./year. It implies that mitigation measures cannot be applied under the cost of less than $0 \mathrm{US} \$ / \mathrm{tCO}_{2}$ eq. Meanwhile, the cost of less than $10 \mathrm{US} \$ / \mathrm{tCO}_{2}$ eq. generates mitigation potential of around $0.01 \mathrm{MtCO}_{2}$ eq./year and can be applied only with agro-forestry (AGF). The cost of less than 20US $\$ / \mathrm{tCO}_{2}$ eq. generates $\mathrm{GHG}$ emissions mitigation potential of around $0.02 \mathrm{MtCO}_{2}$ eq./year, while the cost ranging from less than $50 \mathrm{US} \$ / \mathrm{tCO}_{2}$ eq. and above contributes to the same mitigation potentials of around $8.89 \mathrm{MtCO}_{2}$ eq./year. The result suggests that the cost of less than $50 \mathrm{US} \$ / \mathrm{tCO}_{2} \mathrm{eq}$. is the most cost effective mitigation potential in Cambodia whereby reduced impact logging (RIL) generates the largest mitigation potentials, followed by agro-forestry (AGF) and reforestation-fast growing species (RFS).

Table 11: GHG Mitigation potentials ( $\mathrm{MtCO}_{2}$ eq./year) in different costs

\begin{tabular}{|c|c|c|c|c|c|c|c|}
\hline $\begin{array}{l}\text { Mitigation measures } \\
{\left[\mathrm{US} \$ / \mathrm{tCO}_{2} \text { eq.] }\right.}\end{array}$ & CODE & 0 & 10 & 20 & 50 & 100 & Max.* \\
\hline Plantation-short rotation & PSR & 0.0 & 0.0 & 0.0 & 0.0 & 0.0 & 0.0 \\
\hline Plantation-long rotation & PLR & 0.0 & 0.0 & 0.0 & 0.0 & 0.0 & 0.0 \\
\hline $\begin{array}{l}\text { Reforestation-fast } \\
\text { growing species }\end{array}$ & RFS & 0.0 & 0.0 & 0.01 & 0.01 & 0.01 & 0.01 \\
\hline $\begin{array}{l}\text { Reforestation-slow } \\
\text { growing species }\end{array}$ & RSS & 0.0 & 0.0 & 0.0 & 0.0 & 0.0 & 0.0 \\
\hline $\begin{array}{l}\text { Enhanced natural } \\
\text { regeneration }\end{array}$ & ENR & 0.0 & 0.0 & 0.0 & 0.0 & 0.0 & 0.0 \\
\hline Agro-forestry & $\mathrm{AGF}$ & 0.0 & 0.01 & 0.01 & 0.01 & 0.01 & 0.01 \\
\hline Reduced impact logging & RIL & 0.0 & 0.0 & 0.0 & 8.87 & 8.87 & 8.87 \\
\hline Total & & 0.0 & 0.01 & 0.02 & 8.89 & 8.89 & 8.89 \\
\hline
\end{tabular}


The maximum mitigation potential at the cost without considering economic constraints (technical potential) is expected to mitigate GHG emissions by around $8.89 \mathrm{MtCO}_{2}$ eq/year in 2050 .

\section{DISCUSSION}

According to the results, the agricultural sector is a net emitter and the cumulative emissions increase considerably between 2010 and 2050. In contrast, the LULUCF sector is a net carbon sink in 2010 and 2050. The estimated results of emissions by sources in the agricultural sector in 2010 of this study were very similar to the SNC's one (Figure 1); however, in the LULUCF sector, this study found that both emissions and sink capacity were slightly lower than the SNC's ones in the base year (Figure 2). This may result from the differences in assumptions and limited access to data in the SNC.

The result yields that the most effective mitigation measures in the agricultural sector can be applied with the cost of less than $10 \mathrm{US} \$ / \mathrm{tCO}_{2}$ eq.; however, it cannot be applied under the LULUCF sector where the most plausible mitigation measures are applied with the cost of less than $50 \mathrm{US} \$ / \mathrm{tCO}_{2}$ eq. Besides, the mitigation potential in the AFOLU sector will be much higher than that of the energy sector. BL emissions are projected to be about $20.8 \mathrm{MtCO}_{2}$ eq./year in the energy sector in 2045 under the $\mathrm{SNC}^{5)}$ and about $66.8 \mathrm{MtCO}_{2}$ eq./year in the AFOLU sector in 2050 for this study. From the BL emissions, $5.4 \mathrm{MtCO}_{2}$ eq./year (26\%) of energyinduced emissions ${ }^{5)}$ and $31.5 \mathrm{MtCO}_{2}$ eq./year (47\%) of the AFOLU sector can be mitigated at maximum. Therefore, the application of mitigation measures in the AFOLU sector has a greater potential to reduce emissions at this cost level in Cambodia.

Furthermore, this study suggests that the land limitation to apply mitigation measures in the LULUCF sector is one of the main challenges to increase mitigation potentials since increase of land area for forest plantation will decrease other land areas (e.g. cropland and settlement), while the SNC does not take the land limitation into account. In order to improve the future analysis, additional studies are needed especially by combining the model to another model to assess mitigation potential under different assumptions; for instance, improving crop intensity and productivity can reduce the demand for cropland area, building more compact cities can reduce the demand for settlement area, and improving feeding sources and alternative healthy diet can reduce meat demand from livestock, etc. Thus, Cambodia has more land to increase forest plantations, which helps reduce deforestation and increase reforestation and afforestation, etc.

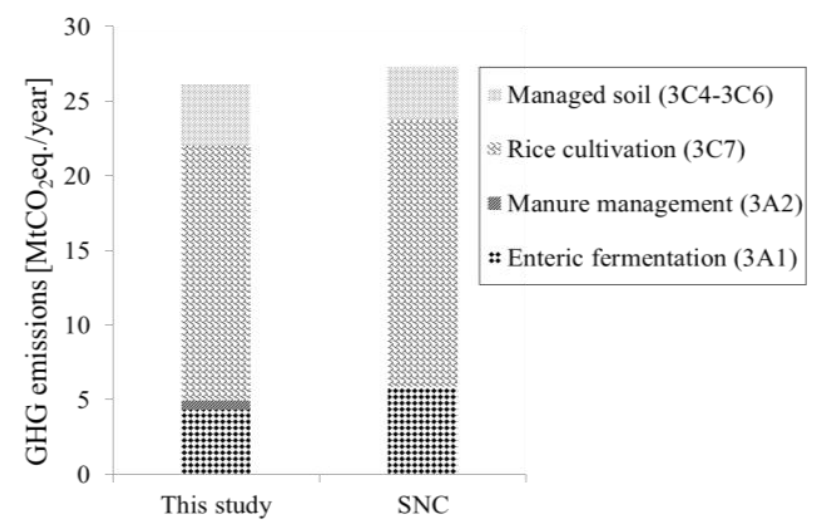

Figure 1: Comparison of GHG emissions in the agricultural sector between this study and SNC

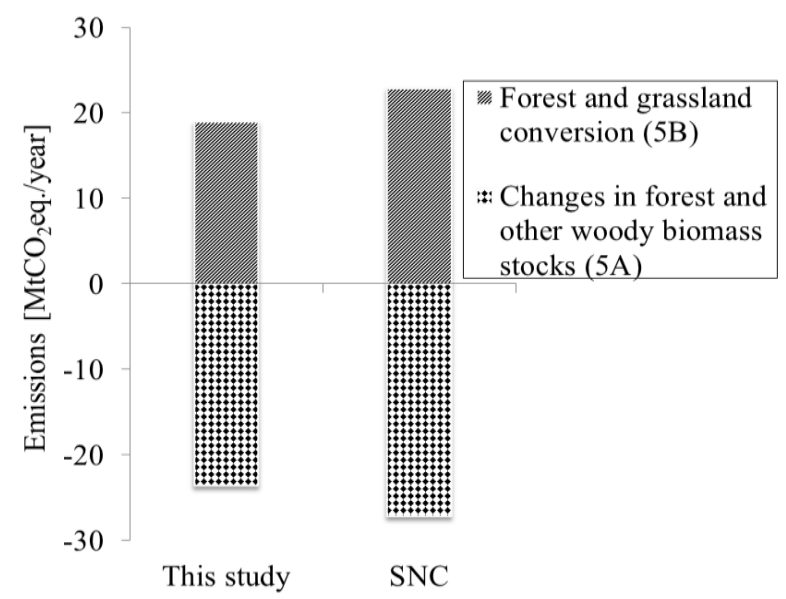

Figure 2: Comparison of GHG emissions in the LULUCF sector between this study and SNC

\section{FINAL REMARKS}

The Government strongly reaffirmed that the country development must adhere to the agricultural sector not only at present but also in the future. The AFOLU sector contributed more than $90 \%$ of total national GHG emissions in 2000. By implementing mitigation measures in this sector, Cambodia is expected to contribute not only to reducing anthropogenic GHG emissions but also improving land management, crop productivity and ensuring sustainable forest management. The results of this study are expected to play a very important role to brainstorm and provide insights for the Government to formulate the national policy or strategy for climate change mitigation in the AFOLU sector. 
This study explores GHG mitigation potential under different costs and mitigation measures whereby the following findings are discovered.

- Under the baseline case, the AFOLU sector is projected to change from a net carbon sink $\left(0.94 \mathrm{MtCO}_{2}\right.$ eq./year $)$ in 2010 to a net emitter (13.98 $\mathrm{MtCO}_{2}$ eq./year) in 2050;

- In the agricultural sector, GHG emissions are projected to increase about 3 times in 2050;

- The cost of less than 0US $\$ / \mathrm{tCO}_{2}$ eq. generates mitigation potentials of $5.96 \mathrm{MtCO}_{2}$ eq./year;

- The cost of less than 10US $\$ / \mathrm{tCO}_{2}$ eq. generates emissions reduction of $20.55 \mathrm{MtCO}_{2}$ eq./year;

- The cost ranging over $10 \mathrm{US} \$ / \mathrm{tCO}_{2}$ eq. does not cause a great increase in emissions reduction;

- The technical mitigation potential is expected to reach $22.65 \mathrm{MtCO}_{2}$ eq./year in 2050;

- In the LULUCF sector, the carbon sink capacity is projected to increase from $27 \mathrm{MtCO}_{2}$ eq./year in 2010 to $53 \mathrm{MtCO}_{2}$ eq./year in 2050 ;

- The cost of less than 0US $\$ / \mathrm{tCO}_{2}$ eq. generates mitigation potentials of $0 \mathrm{MtCO}_{2}$ eq./year;

- The cost of less than $10 \mathrm{US} \$ / \mathrm{tCO}_{2}$ eq. generates mitigation potential of $0.01 \mathrm{MtCO}_{2}$ eq./year;

- The cost of less than 20US $\$ / \mathrm{tCO}_{2}$ eq. generates mitigation potential of $0.02 \mathrm{MtCO}_{2}$ eq./year;

- The cost of less than $50 \mathrm{US} \$ / \mathrm{tCO}_{2}$ eq. and above reduces emissions of ( $8.89 \mathrm{tCO}_{2}$ eq./year);

- The technical mitigation potential is expected to reach $8.89 \mathrm{MtCO}_{2}$ eq./year in 2050 ; and

- In sum, the cost of less than $10 \mathrm{US} \$ / \mathrm{tCO}_{2}$ eq. is the most effective mitigation potentials for the agricultural sector and of $50 \mathrm{US} \$ / \mathrm{tCO}_{2}$ eq. for the LULUCF sector.

ACKNOWLEDGEMENT: The preliminary version of the paper was presented at a workshop on the "Advancement and Enhancement on Low Carbon Development Researches and Policies among Cambodia, Lao PDR and Myanmar on 26 February 2015 in Phnom Penh, Cambodia. This research was supported by "Environmental Research and Technology Development Fund by the Ministry of Environment, Japan”, 2-1402.

\section{REFERENCES}

1) UNFCCC, 1992. United Nations Framework Convention on Climate Change. Available at www.unfccc.int/ resources.

2) UNFCCC, 2011. United Nations Framework Convention on Climate Change. Available at http://unfccc.int/ resource/docs/2011/cop17/eng/09a01.pdf.

3) Luderer, G., Pietzcker, R. C., Kriegler, E., Haller, M., and Bauer, N., 2012. Asia's role in mitigating climate change: a technology and sector specific analysis with ReMIND-R Energy Econ. 34 S378-90.

4) Luderer, G., Pietzcker, R. C., Bertram, C., Kriegler, E., Meinshausen, M., and Edenhofer, O., 2013. Economic mitigation challenges: how further delay closes the door for achieving climate targets.

5) Ministry of Environment (MoE), 2013. Draft Second National Communication. Phnom Penh, Cambodia.

6) Royal Government of Cambodia (RGC), 2010. National Forest Programme (2010-2029) of MAFF. Cambodia.

7) H.E Chea Sam Ang, Deputy Director General of Forestry Administration (FA) of MAFF. The implementation of National Forest Programme. Direct interview in 2013.

8) Mr. Leng Chivin, Dept. of FA. Forest Cover and Land Use Classifications. Direct interview in 2013 and 2015.

9) Royal Government of Cambodia (RGC), 2014. National Strategic Development Plan (2014-2018). Cambodia.

10) Royal Government of Cambodia (RGC), 2011. Cambodia Forest Cover 2010 of MAFF. Cambodia.

11) Royal Government of Cambodia (RGC), 2015. The Strategic Planning Framework for Livestock (2015-2024) of MAFF. Cambodia.

12) Ministry of Environment (MoE), 2013a. Cambodia Climate Change Strategic Plan (2014-2023). Cambodia.

13) Hasegawa T., and Matsuoka Y., 2013 Climate Change Mitigation Strategies in Agriculture and Land Use in Indonesia. Mitigation and Adaptation Strategies for Global Change, 20 (3): 400-424.

14) Tahsin, J., Hasegawa, T., Matsuoka, Y., 2014. Climate Change Mitigation in the AFOLU sector in Bangladesh. Mitigation and Adaptation Strategy of Global Change.

15) Nguyen, T. H., Hasegawa, T., Matsuoka, Y., 2014. Climate Change Mitigation Strategies in the AFOLU sector in Vietnam. Mitigation and Adaptation Strategy of Global Change 19:15-32.

16) National Institute of Statistics (NIS), 2012. Cambodia Socio-economic Survey 2010. The NIS of the Ministry of Planning. Phnom Penh, Cambodia.

17) Bates, J., 1998. Technologies to Reduce $\mathrm{CH}_{4}$ emission. AEAT Environment 3773(3). Environmental Economics. http://ec.europa.eu/environment/enveco/climate_change/ index.htm.

18) Shibata M., Fuminori T., 2010. Factors Affecting $\mathrm{CH}_{4}$ Production and Mitigation in Ruminants. Animal Science Journal 81(1), 2-10. 
19) Golan, A., Judge, G., Miller, D., 1996. Series in Financial Economics and Quantitative Analysis, Maximum Entropy Econometrics, Robust Estimation with Limited Data. Wiley. New York, USA.

20) Graus, W., Harmelink, M., Hendriks, C., 2004. Marginal GHG-abatement Curves for Agriculture. Ecofys, Utrecht.

21) Hendriks, CA., De Jager, D., and Blok, K., 1998. Emission Reduction Potential and Costs for $\mathrm{CH}_{4}$ and $\mathrm{N}_{2} \mathrm{O}$ in the EU-15. Interim Report by Order of DGXI, EC, M714, ECOFYS, Utrecht, Netherlands.

22) Amann, M., Hoglund Isaksson, L., Winiwarter, W., Tohka, A., Wagner, F., Schopp, W., Bertok, I., Heyes, C., 2008. Emission Scenarios for Non- $\mathrm{CO}_{2}$ GHGs in the EU-27. Mitigation Potentials and Costs in 2020. http://ec.europa. eu/climate/policies/package/docs/ir_07_nonco 2 _en.pdf.

23) Akiyama, H., Yan, X., Yagi, K., 2010. Evaluation of Effectiveness of Enhanced-Efficiency Fertilizers as Mitigation Technologies for $\mathrm{N}_{2} \mathrm{O}$ and $\mathrm{NO}$ emission from Agricultural Soils: Meta-analysis. Global Change Biology 16(6), 1837-1846.

24) Smith, P., Martino, D., Cai, Z., Gwary, D., Janzen, HH., Kumar, P., McCarl, B., Ogle, S., O’Mara, F., Rice, C., Scholes, RJ., Sirotenko, O., Howden, M., McAllister, T., Pan, G., Romanenkov, V., Schneider, U., Towprayoon, S., Wattenbach, M., Smith, JU., 2007. GHGs Mitigation in Agriculture. Phil Trans Roy Soc B 363:789-813. doi:10.1098/rstb.2007.2184.

25) Intergovernmental Panel on Climate Change (IPCC), 2006. IPCC Guidelines for National Greenhouse Gas Inventories. Volume 4. The AFOLU sector.

26) National Institute of Statistics (NIS), 2011. Statistical Year Book of Cambodia 2011. The NIS of the Ministry of Planning. Phnom Penh, Cambodia.

27) Ministry of Agriculture, Forestry and Fisheries (MAFF), 2011. Annual Report 2011 and Its Target 2012. Cambodia.

28) Mr. Am Phirum, Deputy Director of Dept. of Agronomy. Crop Production in Cambodia. Direct interview in 2013.

29) FAO, 2010. FAOSTAT Statistical Data. Available online at http://faostat.fao.org/default.aspx.

30) Sovan, S., 2010. Land Reform in Cambodia. Presented at FIG Congress 2010: Facing Challenges Building Capacity on 11-16 April 2010. Sydney, Australia.

31) United Nations (UN), 2011. World Population Prospects: 2010 and 2012 Revision. Vol. I: Comprehensive Tables. Dept. of Economic and Social Affairs, NY City, USA.

32) Mr. Kong Kimsreng, Programme Officer of the International Union for Conservation of Nature (IUCN). Status of Wetland in Cambodia. Direct interview in 2014.

33) Bun Heng, S., 2002. Desk Study on National Wood Fuels and Wood Energy Information Analysis. Cambodia.
34) Food and Agriculture Organization (FAO), 2010a. Global Forest Resources Assessment 2010. Rome, Italy.

35) Mr. Chhup Thavith, Officer of Dept. of Planning and Statistics (MAFF). Fertilizer Demand and Consumption. Direct interview in 2014.

36) Ms. Ok Savin, Deputy Director of Dept. of Animal Health and Animal Production, (MAFF). Livestock Demand and Projection in Cambodia. Direct interview in 2015.

37) Mao, H., Matsuoka, Y., and Gomi, K., 2015. Background Report on A Design of Low Carbon Development Action in Cambodia towards 2050: Energy Policy. Kyoto, Japan.

38) Royal Government of Cambodia (RGC), 2010a. Policy Paper on the Promotion of Paddy Production and Rice Export of the Council Ministers. Phnom Penh, Cambodia.

39) Royal Government of Cambodia (RGC), 2011. Mid-Term Review 2011 on NSDP Update 2009-2013. Cambodia.

40) TWG-AG, 2010. Programme Design Document for the strategy for Agriculture and Water 2010-2013. Technical Working Group on Agriculture and Water. Cambodia.

41) Alexandratos, N., and Bruinsma, J., 2012. World Agriculture towards 2030/2050: The 2012 Revision. ESA Working paper No. 12-03. Rome, FAO.

42) Ministry of Agriculture, Forestry and Fisheries (MAFF), 2013. Report 2013 and Its Target 2104. Cambodia.

43) ACI, 2014. Diagnostic Study Cambodia Agriculture in Transition. Draft Final Report. Agrifood Consulting International, Kensington, Maryland, USA.

44) Dr. Meng Bundarith, Director of Dept. of Land Management. Land Use Classification and Management in Cambodia. Direct interview in 2014.

45) Ministry of Environment, 2013. Cambodia Biosafety Clearing House. Available at: http://www.bch -moe. gov.kh/sub/other/6/16/.

46) General Directorate of Rubber (DGR), 2011. Strategy for Natural Rubber Development in Cambodia (2011-2020). General Directorate of Rubber of MAFF. Cambodia.

47) USEPA, 2006. Global Mitigation of Non- $\mathrm{CO}_{2}$ GHG emission. United States Environmental Protection Agency, EPA 430-R-06-005. Washington, DC, USA.

48) DPS. 2014. Annual Report on Fertilizer Import and Export in Cambodia. Dept. of Planning and Statistics of MAFF. Phnom Penh, Cambodia.

49) Vuthy, T., Pirom, K., and Dary, P., 2014. Development of the Fertilizer Industry in Cambodia: Structure of the Market, Challenges in the Demand and Supply Sides and the Way Forward. CDRI Working Paper Series No. 91.

50) FAO, 2004. Fertilizer Requirements in 2015 and 2030 revisited, Land and Plant Nutrition Management Service Land and Water Development Division, Rome.

(Received April 7, 2015) 